ECONOMIC THEMES (2019) 57(1): 1-20

DOI 10.2478/ethemes-2019-0001

\title{
CREATING CONSUMER LOYALTY IN THE FIELD OF USING OVER-THE-COUNTER PRODUCTS
}

\author{
Srđan Šapić \\ University of Kragujevac, Faculty of Economics, Republic of Serbia \\ $\bowtie$ ssapic@kg.ac.rs
}

\section{Milan Kocić}

University of Kragujevac, Faculty of Economics, Republic of Serbia

$\bowtie$ mkocic@kg.ac.rs

\section{Katarina Radaković}

University of Kragujevac, Faculty of Economics, Republic of Serbia

$\bowtie$ kradakovic@kg.ac.rs

UDC

366.1

Original

scientific paper

Received: 09.12.2018 Accepted: 28.02.2019
Abstract: Consumer behaviour, primarily in terms of examining consumers' loyalty, as one of the key marketing ideas, represents a subject of consideration in many areas. One of them is pharmaceutical marketing. This paper places a special focus on the examination of over-the-counter products, i.e. it tries to identify which variable has the greatest impact on loyalty towards these products. By using the quantitative analysis, it was examined whether perceived risk, pharmacist expertise, promotional activities and price sensitivity affect the creation of consumer loyalty. In addition, the aim was to determine whether consumer loyalty to over-thecounter products results in buying behaviour. Based on the applied correlation and regression analysis, it was confirmed that perceived risk and pharmacist expertise have a statistically significant impact on consumer loyalty, and that there is a statistically significant relationship between consumer loyalty and readiness to purchase.

Keywords: over-the-counter products, consumer loyalty, perceived risk, pharmacist expertise, price sensitivity, promotional activities

JEL classification: D910, I120 


\section{Introduction}

In modern conditions of doing business, the application of marketing tools within the company, its existence and functioning represents an unavoidable business philosophy. Regardless of the type of business they do, companies have realised that the implementation of marketing activities is one of the key determinants of their development and a prerequisite for the improvement of their business performances. The marketing concept is being used in an increasing number of industries, in order to meet the consumers' needs in the best possible way and to achieve a competitive advantage. In marketing literature, one of the areas that is increasingly capturing researchers' attention is pharmaceutical marketing. A special part and a good basis for the realisation of marketing activities, refers to OTC (over-the-counter) products which can be bought without a prescription. This is the reason why the space for the demonstration of the effects of using the marketing concept is larger with these products. Within this area, the idea is to keep the consumer, as the centre of the marketing efforts and directions, as long as possible, i.e. to create consumer's loyalty. By using numerous tools of marketing mix - product, price, promotion and distribution, the idea is to influence consumers' positive attitudes that would achieve positive relations and establish a mutually trusting relationship. There are numerous factors that influence the choice of the consumer in the increasingly turbulent conditions of the environment. The pharmaceutical industry, as one of the fastest growing areas, can also be one of the examples which show how the appropriate implementation of the marketing strategy contributes to success. With a special emphasis on the fact that this is the area related to the health of the consumers, there are many determinants which affect their decisions and choice of certain products. In accordance with the previously analysed studies, the idea here is to examine which of these factors have the decisive significance for consumer behaviour, i.e. which factors create the platform for decision-making process the most. Additionally, with the use of the quantitative analysis, the attitudes of consumers regarding the purchase of products will be examined, and it will also be determined if there are differences when analysing the factors which form their loyalty. The following variables have been selected to be a part of the model as the most significant ones: perceived risk, pharmacist expertise, promotional activities and consumer price sensitivity. Therefore, their analysis will identify their impact on consumer loyalty in OTC product market.

\section{Literature review}

\section{Pharmaceutical marketing and OTC products}

Based on the basic concept of marketing to adequately contribute to the increase of the demand for products or services by meeting the individual and social needs 
(Kotler \& Keller, 2007), it can be reasonably stated that its increasing use is evident in numerous areas. One of them is pharmaceutical marketing, whose use has gained importance in recent years and which represents the subject of involving concepts from many disciplines. The paper will particularly focus on pharmaceutical marketing in the area of OTC (over-the-counter) products, having in mind that these products can be purchased of consumer's own choice, without the obligation to obtain a prescription for them, i.e. expert's permission. In most European countries, the regulations that refer to the healthcare system are increasingly becoming consumer-oriented (Holmström et al., 2014), which only confirms the significance of marketing, and primarily the correlation of the investigation of consumers' behaviour when it comes to using OTC products. Considering the growing independence of consumers when choosing products or services, it is very important to identify the criteria that can contribute to their purchase properly. The use of marketing concept in the pharmaceutical industry is becoming increasingly more present, especially if we consider the fact that experts in the pharmaceutical sector are moving away from the classical approach, which comes down to solving health problems, towards an approach which places the patient himself/herself (the consumer) at the centre of doing business, i.e. his/her satisfaction and keeping long-term relationships with him/her in order to maximise the quality of the provided service (Guido et al., 2011). The fact that OTC products are perceived as safer for the health system by the consumers and that they can be obtained without a prescription, points to the need for their renewed consideration. The basic determinants of OTC products are primarily seen in the following statements (Rowley, 2014):

- OTC products should be labeled in such a way that the consumer is able to independently identify the symptoms, and by using these products to affect their proper treatment;

- The possibility of misusing these products is low, as well as their negative effects;

- Safety margins for consumers' health should be posed in such a way that the benefits referring to their use surpass the risk that may arise by that.

The analysis of the use of these products demands a previous understanding of their significance by the user, as well as an evaluation of numerous criteria which refer to the sociological and psychological characteristics of the consumers. Due to the increasingly fierce competition in the pharmaceutical industry, numerous marketing strategies can be of crucial importance to the realisation of business performances, improvement of financial indicators and differentiation compared to other market participants (Wieringa et. al., 2015). Even though the consumers' general opinion is that OTC products possess a higher degree of safety, their use can have negative implications as well (Cooper, 2013), especially if the specified instructions related to the proper use and dosage of the medicine are not followed. Sociological and economic factors are listed as the most common variables which 
affect the increasingly more common tendency of the consumers to deal with health symptoms that appear without getting a prescription, i.e. by using the so-called selfmedication concept (Almalak et al., 2013). Although the area of OTC products is extremely well represented, there are few papers which deal with this issue from the marketing point of view, thereby pointing out the individual and shared effect of factors which have the greatest impact on the purchase of the products and loyalty to them by the consumers. The deregulation of the systems in the area of healthcare and the placement of promotional messages have led to the situation that bigger promotional budgets become allocated to the representation of these products, bringing them closer to certain target groups. Some of the most commonly listed advantages of the use of such products compared to those which require a prescription are saving time, as well as additional costs related to more frequent visits to healthcare facilities (Cho \& Lee, 2013). Even though OTC products can be classified as the group of consumer goods (due to some of their properties, their complexity and certain differences make them most commonly perceived, in different contexts, primarily as medications (Wieringa et al., 2015). There are numerous classifications of OTC products, and for the needs of this paper, we will point out those that appear in the largest number of relevant papers associated with the given problem. These are: (Cho\& Lee, 2013, Porteous et al., 2005)

- products against colds,

- analgesic drugs,

- nutritional products,

- dietary supplements,

- painkillers

Numerous authors have identified some of the most significant factors which affect the purchase of OTC products. For the needs of this paper, some of the most significant variables will be explained first, and they will be seen in the context of constructing the research model. Therefore, the research model will primarily encompass the questions referring to whether there are differences when considering the factors which determine consumers' purchase compared to those which affect their loyalty when it comes to OTC products. Before moving on to the research, some of the basic theoretical concepts which are of interest to the author will be explained.

\section{Pharmacist expertise}

There are many instances of research where the focus is placed on the role which experts, in this case pharmacists, have during the choice and use of appropriate OTC products. Their role has been growing in the past years, having in mind the fact that the consumers are facing a large number of alternatives, for whose choice a trustworthy advice from a reliable person is necessary. Unlike in the past, when the consumers showed an insufficient degree of trust and a kind of skepticism 
when choosing those products, in modern times a higher degree of credibility towards these people has been noticed, whose main role refers to the transfer of correct and precise information, which provides certainty and help with the decision-making process concerning the purchase (Villako et al., 2012). The research shows that pharmacists are mostly perceived as the most significant carriers of information about these products, which supports the idea that their adequate training is very important for the realisation of these products, as well as consumer satisfaction. Moreover, it has been determined that pharmacists are the most common source of information, and they are those who determine the decision of the consumer and have a positive effect on their readiness to complete the purchase (Hayashi et al., 2015). The emergence of consumer dissatisfaction, when it comes to the advisory role of the pharmacist, mostly refers to the lack of the needed information (Villako et al., 2012). The decentralisation of the healthcare system has led to an increasing intensification of the power of marketing and communication with the consumers (Health Research Institute, 2013), so in that sense, it is not surprising that many consumers perceive pharmacists as the main source of information about OTC products. Even though the process of digitalisation and development of information and communication technologies has brought about an increasing independence of the consumers during the process of collecting information about these products, many of them still prefer this form of verbal communication to other forms. Still, regardless of the readiness of the consumers to seek advice from an expert, some of the most important obstacles that contribute to the fact of not giving enough credit to the importance of such dialogues are queues in pharmacies, as well as a lack of privacy. Namely, many studies have concluded that, for a complete effect and readiness of the consumer to talk to the pharmacist, it is necessary to create an ambiance that will enable the communication with the pharmacist, without the presence of other consumers (Piecuch et al., 2013). In most countries, the professionalism of pharmaceutical representatives refers to their responsibility for providing appropriate information concerning the dosage and use of OTC products, as well as their proper use when the first symptoms appear (Guido et al., 2011). The paper poses the following hypothesis:

H1: Pharmacist expertise has positive implications regarding consumer loyalty to OTC products.

\section{Perceived risk}

Even though OTC products are mostly attributed a higher degree of safety for health compared to prescription-only medications (Glasziou, 2002), the risk associated with their use is still one of the factors that are often analysed in the case of their purchase (Almalak et al., 2014). In order to minimise numerous negative effects which the consumers might encounter while using OTC products, FDA 
regularly updates the information related to the risks associated with their use, thereby pointing out that they are safe for health, if the instructions written on the packaging are followed by the combination of the dosage defined by an expert. Also, the research in the field of pharmaceutical industry has shown that these products cannot be assigned a label due to the fact that their use completely eliminates the risk to the health system (Creyer et al., 2001). Still, considering typically lower concentration of certain bad substances and the possibility to use them of one's own choice, the risk is lowered with the proper implementation of marketing strategies, the transfer of an adequate and true message, as well as the packaging which adequately points out all the benefits, as well as the dangers of their use. In relation to that, certain suggestions are pointed out in order to increase the consumers' perceived safety when purchasing OTC products (Weiss, 2009): increasing the font that will point out the facts about an OTC product, explicitly pointing out why it is important to follow proper instructions and what will happen if that is not done. Starting from the perceived risk, for the needs of the research the following hypothesis is formulated:

H2: Perceived risk related to the use of OTC products affects consumer loyalty.

\section{The significance of promotional activities to OTC products}

For the purpose of making the products or services closer to the consumers, attracting their attention and resulting in purchase, the companies in the field of pharmaceutical industry have recorded an increasingly intensive use of promotional activities. Even though there are numerous communication sources in this, as well as other areas of the implementation of marketing concepts, for the purpose of this paper, it would be significant to examine how the commercials using various media (television, radio, newspapers, health magazines) are relevant for the purchase of and loyalty to OCT products. Since more and more money is spent on the purchase of OCT products, the use of promotional activities in this area has a special importance, considering the fact that it arises as a result of motivational research of consumer behaviour. It often happens that consumers perceive that one company is more successful than the competition based on the promotional activities, which additionally favors the given company when they make a decision (Chandra \& Holt, 1999). For the purpose of maximising business results, as well as consumer satisfaction, it is very important for the experts in the field of pharmaceutical industry to identify the significance of marketing strategies referring to the placement of appropriate information about products. Even though most promotional activities are done in order to maximise profits, in this case it should not be forgotten that the essential issue for the creators of promotional appeals is primarily the consumers' health. Consumers can acquire information about OTC products, which can significantly determine their decision, using numerous media, such as television, internet, radio, professional publications. 
Plenty of research defines precisely the promotion of OTC products as a dominant source of information for the consumers, thereby pointing out that consumers mostly exhibit a higher tendency towards the use of such products, if they are supported by adequate promotional content (Haddad et al., 2013). In accordance with that, the following hypothesis is formulated:

H3: Promotional activities related to OTC affect consumer loyalty.

\section{Consumer price sensitivity}

For the purpose of better positioning themselves in the market, and achieving a competitive advantage, many business entities have realised the importance of an adequate formation of price policies, regardless of the area in which they conduct their business activities. A lot of research has shown that the price of OTC products represents one of the key factors which affects the consumer's decision (Piecuch et al., 2013). The possession of knowledge regarding the level of prices of a product which belongs to an evoked set of consumers' awareness often has the decisive significance to their evaluation of the product and the readiness to complete the purchase (Rosa-Díaz, 2004). The price component must definitely be taken into account when choosing an OTC product, because some consumers are willing to change as many as two or three pharmacies, i.e. retail objects, in order to meet their demands at the lowest possible price (Bahari \& Ling, 2010). The price is also seen as an indicator of perceived quality, especially in the fields of the service sector (Jobber \& Fahy, 2007). Some consumers are willing to spend more money compared to others for the same or similar product, depending on the identification with certain products or their loyalty to them, which will be discussed in detail later in the paper. The price component is definitely an unavoidable point during the decision-making process for the consumers, concerning the purchase. Namely, while considering numerous alternatives at their disposal, consumers will sometimes perceive the price as a reflection of the value they get for a certain product or service. In that sense, in the case of OTC products it is necessary to identify how much the price sensitivity can imply the consumer's choice. And while some authors believe that a lower price will be an indicator of a lower quality (Olbrich \& Jansen, 2014), some consumers will be willing to pay even considerably higher prices for some branded products, thus proving a dose of authenticity and prestige that they have in the society (Lichtenstein et al., 1993). A low price of OTC medicines does not signify the readiness of the consumer to do the purchase again, but it is also important to offer the right relationship between price and quality (Lodorfos et al., 2006). The same research has identified that the lower the price sensitivity, the higher degree of trust that the consumers have in a certain OTC product is. This paper will examine whether the price sensitivity affects the consumer loyalty, starting from the following hypothesis:

H4: Consumer price sensitivity affects the loyalty to OTC products. 


\section{Consumer loyalty to OTC products}

Considering the fact that consumers represent a very important and interesting group which the success and prosperity of a company depends on, forming longterm relationships with them, it can significantly contribute to the improvement of business results. Because of that, companies see the concept of consumer loyalty as an unavoidable part of marketing research. Regardless of the consumer's satisfaction with the purchased OTC product, it does not necessarily have to lead to a repeated purchase and the continuation of cooperation, much in the same way as consumer loyalty does not necessarily have to lead to buying behaviour. In modern conditions of doing business, consumers are characterised by a constantly increasing level of being informed, so it is crucial that the factors which lead to the possibility of a once-made purchase continuing in the future are identified. The degree to which a consumer is satisfied with the purchased product reflects on the future choice of the same product (Maričić, 2002).

This only confirms the assumption that we have to approach the process of testing consumer behaviour in a systematic, planned and adequate manner. By identifying the consumer's needs and requirements regarding the purchase of OTC products, as well as by the placement of the correct information, we provide the conditions for establishing a relationship of trust and commitment. Consumer loyalty is also characteristic of the purchase of OTC products, which was confirmed by the research (Mardanov \& Ricks, 2013), so the goal of our paper is to examine which of the variables presented in the research model has the greatest impact on consumer loyalty. In order to maximise customer satisfaction and to create their loyalty, a number of marketing instruments that have been explored while studying loyalty in the OTC industry can be listed. Some of them relate to the following (Lostakova \& Horakova, 2014).

- high quality products at an affordable price,

- providing superior services,

- intensive and effective communication with consumers,

- promotional activities,

- numerous loyalty programmes.

Marketing strategies should be implemented in such a way, so as to give the consumer the feeling of greatest satisfaction (Maričić, 2002). Consumer loyalty represents the commitment of a consumer to a particular brand of a product, store or supplier, which is based on a strong positive attitude and is reflected in continuous repeated purchases (Marinković, 2008, p.144). Having in mind the fact that there is an increasing number of places where OTC products can be purchased, consumers are given a wider choice of available options, which leads to the fact that if the consumer is not completely satisfied with the purchased product, he/she can take into consideration the offer of other market participants. In order to avoid 
this, it is necessary to identify a number of factors contributing to consumer loyalty, which implies both a reduction in marketing costs (Zakaria et al., 2014), but also other resources that need to be allocated, so as to attract new consumers. One of the goals of our paper is to identify whether consumer loyalty influences the consumer's intention to make a purchase, which is examined by starting from the following hypothesis:

H5: Consumer loyalty towards OTC products has positive implications on consumers' purchase intention.

\section{Empirical research of factors affecting the purchase and loyalty of consumers of OTC products}

\section{Research methodology}

The subject of this research is to examine the relationship between factors affecting the purchase and the loyalty, when it comes to OTC products. The main goal of the research is to obtain relevant information about whether the pharmacist expertise, the perceived risk associated with the use of these products, promotional activities and price sensitivity affect the loyalty of consumers, and also whether there are differences in the observation of these factors when shopping and loyalty are observed separately. The derived goal refers to finding relevant information on whether there is a statistically significant link between loyalty and purchasing, or whether loyal consumers show a higher degree of buying behaviour.

The research, that will be carried out in order to make final conclusions, relies on previous achievements in this field, where the subject of consideration and expert elaboration of the authors were precisely the factors that influence the purchase of OTC products (Villako et al., 2012, Pileggi, 2015, Shohel et al., 2013). However, the essential differences and contribution refer to the lack of research about the importance of marketing in our country, as well as to the fact that the factors examined will be observed especially from the aspect of purchasing and loyalty, in order to identify whether there are statistically significant differences when it comes to these two marketing concepts. We used a questionnaire for gathering data, whose modification, in accordance with statistical methods, will achieve relevant information. The questionnaire is structured in such a way that besides general data on respondents such as sex, age, education, working status, monthly income, there are also statements related to factors that influence the loyalty regarding OTC products. Respondents showed the degree of agreement with the statements in the questionnaire by using the five-point Likert scale (number 1 - I strongly disagree, number 5 - I strongly agree), which is one of the most commonly used methods for making valid conclusions in this type of research. 
For each of the factors mentioned above, we used certain statements, which are theoretically based on the results of previous research and which are adjusted accordingly. In this way, the perceived risk was evaluated by the first 7 findings, which are adjusted accordingly (Almalak et al., 2014), the pharmacist expertise was analyzed by responding to statements 8-12 (adapted according to Kwan et al., 2008, Piecuch et al., 2013); advertising campaigns were evaluated through the statements 13-16 (Haddad et al., 2013, Hayashi et al., 2015), consumers' price sensitivity through statements 17-20 (Lodorfos et al., 2006), aspects relating to the purchase of OTC products through statements 21-24 (Shohel et al., 2013), while the last four conclusions concern consumer loyalty (Marinković, 2012).

In order to examine the relationship among the observed variables, the hypotheses were tested by using descriptive statistics, correlation analysis, as well as simple and multiple regression. Data analysis was carried out in the statistical program for social sciences (The Statistical Package for the Social Sciences - SPSS version 21). In order to further analyse the existing problems, the paper starts from the research model presented in the following image.

Figure 1: Author's research model

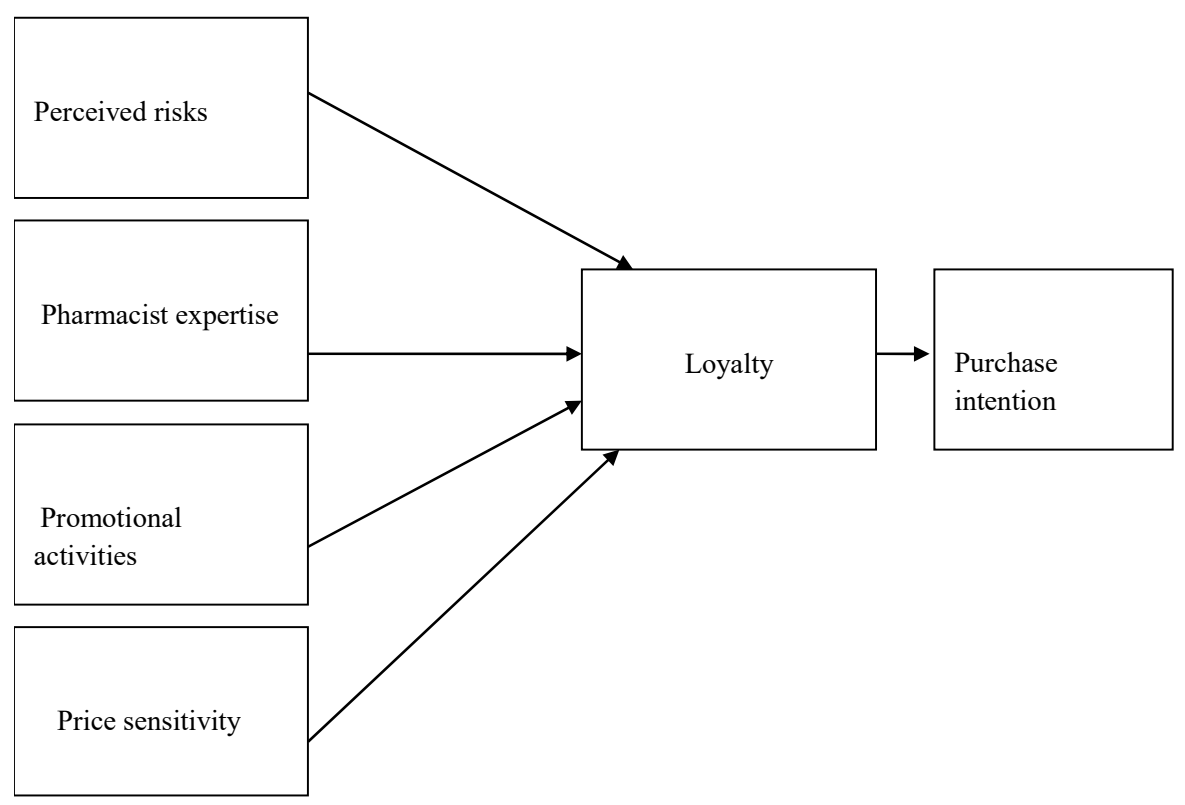

\section{Results of the research}

Empirical research was carried out using the method of survey, as one of the most frequently used method in analyzing consumer behaviour (Marinković et al., 2013, 
p.327). The technique which was used was the questionnaire. Data were collected in the period 20.08-15.09.2017. The questionnaire was distributed to respondents in a classical, physical form. The survey covered 105 respondents of different demographic profiles, which are presented in Table 1.

Table 1. Demographic structure of respondents $n=105$

\begin{tabular}{||l|c|c||}
\hline \multicolumn{1}{|c|}{ Demographic profile } & Frequency & $\%$ \\
\hline Gender & 36 & 34.3 \\
\hline Male & 69 & 65.7 \\
\hline Female & \multicolumn{2}{|c|}{} \\
\hline Age & 7 & 6.7 \\
\hline $18-24$ & 15 & 14.3 \\
\hline $25-31$ & 23 & 21.9 \\
\hline $32-38$ & 3 & 2.9 \\
\hline $39-45$ & 18 & 17.1 \\
\hline $46-52$ & 14 & 13.3 \\
\hline $53-59$ & 25 & 23.8 \\
\hline 60 and more & \multicolumn{2}{|c||}{} \\
\hline Education & 33 & 31.4 \\
\hline Secondary education & 14 & 13.3 \\
\hline Higher education & 58 & 55.2 \\
\hline College education & \multicolumn{2}{|c||}{} \\
\hline Working status & 7 & 6.7 \\
\hline Student & 11 & 10.5 \\
\hline Manager, Entrepreneur & 3 & 2.9 \\
\hline Professor, Medical doctor, Engineer & 73 & 69.5 \\
\hline Clerk & 10 & 9.5 \\
\hline Worker & 1 & 1.0 \\
\hline Retired person & \multicolumn{2}{|c||}{} \\
\hline & \multicolumn{2}{|c|}{} \\
\hline
\end{tabular}

Source: Calculation based on SPSS

By observing Table 1, it can be noted that in the demographic structure of the respondents, women have a higher share in the study (65.7\%), while men are present in the sample with $34.3 \%$. Most of the respondents belong to the category that includes respondents over 60 years $(23.8 \%)$. The smallest number of respondents belong to the age category $39-45(2.9 \%)$ and $18-24$ years $(6.7 \%)$. 
According to the level of education, it can be noted that as many as $55.2 \%$ of the respondents have college education in the examined sample, while the smallest number of respondents is with higher education - $13.3 \%$. In the structure of the sample, a clerk is a workplace that has rounded off $69.5 \%$, while the number of retired people is the smallest (only $1 \%$ ).

In order to determine the homogeneity/heterogeneity of the respondents' attitudes, in the initial step of the analysis we calculated the values of the arithmetic mean and standard deviation for each statement. The results are presented in Table 2.

Table 2. Values of the descriptive statistics (arithmetic mean and standard deviation) for the statements given above

\begin{tabular}{|c|c|c|}
\hline Statements & $\mathbf{M}$ & SD \\
\hline \multicolumn{3}{|l|}{ Perceived risk } \\
\hline $\begin{array}{l}\text { OTC products are safer for health compared to products sold by } \\
\text { prescription. }\end{array}$ & 2.64 & 1.338 \\
\hline $\begin{array}{l}\text { OTC products have less adverse effects on health system, when } \\
\text { compared to prescription medications. }\end{array}$ & 2.76 & 1.334 \\
\hline $\begin{array}{l}\text { Excessive use of OTC products cannot have a serious impact on } \\
\text { the health system. }\end{array}$ & 2.43 & 1.440 \\
\hline $\begin{array}{l}\text { OTC products do not have any negative effects when used with } \\
\text { other medications. }\end{array}$ & 2.41 & 1.222 \\
\hline $\begin{array}{l}\text { It is very important that the OTC product contains precise } \\
\text { instructions for use. }\end{array}$ & 4.75 & .769 \\
\hline $\begin{array}{l}\text { It is very important to indicate on the OTC product how long it } \\
\text { can be used. }\end{array}$ & 4.85 & .617 \\
\hline $\begin{array}{l}\text { It is very important to indicate on the OTC product when it } \\
\text { should stop being used }\end{array}$ & 4.67 & .828 \\
\hline \multicolumn{3}{|l|}{ Pharmacist expertise } \\
\hline $\begin{array}{l}\text { The level of pharmacist/doctor knowledge has a considerable } \\
\text { impact on my decision to buy OTC products. }\end{array}$ & 3.94 & 1.134 \\
\hline $\begin{array}{l}\text { The level of pharmacist/doctor responsibility has a considerable } \\
\text { impact on my decision to buy OTC products. }\end{array}$ & 3.64 & 1.324 \\
\hline $\begin{array}{l}\text { The level of pharmacist/doctor expertise has a considerable } \\
\text { impact on my decision to buy OTC products. }\end{array}$ & 4.00 & 1.109 \\
\hline $\begin{array}{l}\text { The level of pharmacist/doctor persuasive power has a } \\
\text { considerable impact on my decision to buy OTC products. }\end{array}$ & 2.97 & 1.341 \\
\hline $\begin{array}{l}\text { The level of pharmacist/doctor politeness has a considerable } \\
\text { impact on my decision to buy OTC products. }\end{array}$ & 2.77 & 1.409 \\
\hline
\end{tabular}




\begin{tabular}{|c|c|c|}
\hline Promotional activities & & \\
\hline $\begin{array}{l}\text { The advertising of these products on television has the strongest } \\
\text { impact on the purchase of OTC products. }\end{array}$ & 2.69 & 1.443 \\
\hline $\begin{array}{l}\text { The advertising of these products on the radio has the strongest } \\
\text { impact on the purchase of OTC products. }\end{array}$ & 2.00 & 1.118 \\
\hline $\begin{array}{l}\text { The advertising of these products in the newspaper has the } \\
\text { strongest impact on the purchase of OTC products. }\end{array}$ & 2.21 & 1.182 \\
\hline $\begin{array}{l}\text { The advertising of these products in health magazines has the } \\
\text { strongest impact on the purchase of OTC products. }\end{array}$ & 2.66 & 1.216 \\
\hline \multicolumn{3}{|l|}{ Price sensitivity } \\
\hline When buying an OTC product, I buy the cheapest one. & 2.30 & 1.287 \\
\hline If the OTC product is on sale, I rather buy it than other products. & 2.43 & 1.379 \\
\hline $\begin{array}{l}\text { The price of an OTC product is very important to me when I } \\
\text { buy products that I have not used before. }\end{array}$ & 2.88 & 1.299 \\
\hline $\begin{array}{l}\text { When buying an OTC product, the price is more important for } \\
\text { me than the brand. }\end{array}$ & 2.70 & 1.360 \\
\hline \multicolumn{3}{|l|}{ Purchase intention } \\
\hline I purchase OTC products more often than prescription products. & 3.30 & 1.507 \\
\hline $\begin{array}{l}\text { I purchase OTC products as a supplement to prescription } \\
\text { products. }\end{array}$ & 3.00 & 1.308 \\
\hline $\begin{array}{l}\text { I buy OTC products when I identify the very first symptoms, in } \\
\text { the early stage of the disease. }\end{array}$ & 3.80 & 1.282 \\
\hline $\begin{array}{l}\text { I buy OTC products when I do not have enough time to get the } \\
\text { prescription. }\end{array}$ & 3.50 & 1.415 \\
\hline \multicolumn{3}{|l|}{ Loyalty } \\
\hline $\begin{array}{l}\text { If I do not find the OTC product I need in the first pharmacy / } \\
\text { drug store, I will look for it in the next one. }\end{array}$ & 3.97 & 1.228 \\
\hline $\begin{array}{l}\text { If I am satisfied with the OTC product, I am ready to pay a } \\
\text { higher price. }\end{array}$ & 4.19 & 1.084 \\
\hline $\begin{array}{l}\text { If I am satisfied with the OTC product, I am ready to } \\
\text { recommend it to others. }\end{array}$ & 4.40 & .936 \\
\hline $\begin{array}{l}\text { If I am satisfied with the OTC product, I will continue buying it } \\
\text { in the future. }\end{array}$ & 4.44 & .909 \\
\hline
\end{tabular}

Source: Author's calculation based on SPSS

By interpreting the values of descriptive statistics, i.e. by interpreting arithmetic mean and standard deviation, it can be noticed that based on the value of these indicators, respondents generally consider that all the factors examined in the 
paper (perceived risk, pharmacist expertise, promotional activity and price sensitivity) influence their behaviour when it comes to the purchase of OTC products and loyalty towards them. The highest value of the arithmetic mean refers to the statements which are connected to the perceived risk (4.85 and 4.75). The smallest value of the arithmetic mean was observed with the statement which refers to the fact that advertisements on the radio have the biggest impact on the purchase of OTC products (arithmetic mean 2.00), as well as in the newspapers (2.21). By observing the value of standard deviation, it can be concluded that the most homogeneous attitudes of the respondents are in the statement regarding the perceived risk in the use of OTC products and the statement that it is very important to indicate on the OTC products how long they can be used (standard deviation 0.617 ), whereas the highest heterogeneity of attitudes is to be seen with the statement which refers to the fact that respondents buy OTC products more often than prescription products (standard deviation 1.507).

Since all the statements are grouped into 6 variables which refer to OTC products, i.e. the first 7 statements reflect the perceived risk, the other 5 statements reflect the pharmacist expertise, the following 4 statements reflect promotional activities, the next 4 price sensitivity, then next 4 readiness to purchase products, and the last 4 consumer loyalty; for all the groups given above, we calculated Cronbach's alpha coefficient in order to determine the reliability and internal consistency of the statements. The value of this coefficient for all the variables is approximately above 0.7 (from 0.697 to 0.857 ), which is considered to be an acceptable value (Nunnally, 1978), so it can be stated that all variables are reliable and internally consistent. Cronbach's alpha for the entire model is 0.746 .

Table 3. The value of Cronbach's alpha coefficient

\begin{tabular}{|c|c|}
\hline Variables & Cronbach's alpha \\
\hline Perceived risk & 0.707 \\
\hline Pharmacist expertise & 0.785 \\
\hline Promotional activities & 0.857 \\
\hline Price sensitivity & 0.814 \\
\hline Loyalty & 0.808 \\
\hline Purchase intention & 0.697 \\
\hline
\end{tabular}

Source: Author's calculation based on SPSS

Before applying the regression analysis, a correlation analysis was carried out. The results of the Pearson coefficient (Table 4) were presented, where it was noticed that there was a statistically significant connection among some variables, whereas among some other, the connection was not confirmed. The correlation coefficient for independent variables which is in relation to consumer loyalty is, as 
the dependent variable, in the interval from 0.2-0.305, so we can conclude that there is a weak connection (Cohen, 1988 in Pallant, J., p.137). If we observe consumer loyalty, it can be noticed that the strongest correlation is between readiness to purchase and consumer loyalty, i.e. loyal consumers most often show a higher degree of purchasing behaviour (the correlation coefficient is 0.500 ). The correlation is also established between the perceived risk of OTC products and consumer loyalty (the correlation coefficient is 0.281 ), as well as the pharmacist expertise and consumer loyalty (the correlation coefficient is 0.282 ).

Table 4. Intercorrelation matrix

\begin{tabular}{||l|c|c|c|c|c|c||}
\hline \hline Variables & $\mathbf{1}$ & $\mathbf{2}$ & $\mathbf{3}$ & $\mathbf{4}$ & $\mathbf{5}$ & $\mathbf{6}$ \\
\hline $\begin{array}{l}\text { Perceived } \\
\text { risk }\end{array}$ & 1 & $.412^{* * *}$ & .136 & .030 & .071 & $.281^{* *}$ \\
\hline $\begin{array}{l}\text { Pharmacist } \\
\text { expertise }\end{array}$ & $.412^{* *}$ & 1 & $.281^{* *}$ & .142 & .149 & $.282^{* *}$ \\
\hline $\begin{array}{l}\text { Promotional } \\
\text { activities }\end{array}$ & .136 & $.281^{* *}$ & 1 & $.444 *$ & $.234 *$ & -.097 \\
\hline $\begin{array}{l}\text { Price } \\
\text { sensitivity }\end{array}$ & .030 & .142 & $.444^{*}$ & 1 & $.305^{* *}$ & -.055 \\
\hline $\begin{array}{l}\text { Purchase } \\
\text { intention }\end{array}$ & .071 & .149 & $.234 *$ & $.305 * *$ & 1 & $.500^{* *}$ \\
\hline Loyalty & $.281 * *$ & $.282^{* *}$ & -.097 & -.055 & $.500^{*}$ & 1 \\
\hline
\end{tabular}

** Correlation is significant on the level 0,01

$* *$ Correlation is significant on the level 0,05

Source: Author's calculation based on SPSS

After the correlation analysis, we applied a multiple regression analysis to examine which of these variables has a significant impact on consumer loyalty. So, for independent variables, we took: perceived risk, pharmacist expertise, promotional activity and price sensitivity, while consumer loyalty is a dependent variable. The results of the multiple regression analysis are presented in Table 5.

When applying the multiple regression analysis, the problem of multicollinearity often occurs, when independent variables influence each other and make it difficult to examine the influence of each independent variable on the dependent variable. For this reason, the variance factor (VIF) is presented. Its value is less than 10 (range 1.207-1.3280) for all variables, indicating that there is no problem of multicollinearity in the model.

Based on the overview given in Table 5, we can make corresponding conclusions. First of all, when it comes to customer loyalty, the results indicate that 
it is formed mainly under the influence of pharmacists, i.e. their expertise is the thing that mostly contributes to creating loyalty to OTC products $(B=0.254, \mathrm{t}=$ $2.425, \mathrm{p}=0.017)$. Also, in the multiple regression model, it was established that the perceived risk has an impact on consumer loyalty $(\beta=0.202, t=1.993, p=0.049)$, while promotional activities and price sensitivity do not have a statistically significant impact on consumer loyalty.

Table 5. Results of multiple regression analysis (dependent variable is loyalty)

\begin{tabular}{||l|c|c|c|c||}
\hline \multicolumn{1}{|c|}{ Variables } & B & T & Sig. & VIF \\
\hline Perceived risk & .202 & 1.993 & .049 & 1.207 \\
\hline $\begin{array}{l}\text { Pharmacist } \\
\text { expertise }\end{array}$ & .254 & 2.425 & .017 & 1.286 \\
\hline $\begin{array}{l}\text { Promotional } \\
\text { Activities }\end{array}$ & -.190 & -1.786 & .077 & 1.328 \\
\hline Price sensitivity & -.012 & -.120 & .905 & 1.249 \\
\hline
\end{tabular}

Source: Author's calculation based on SPSS

Based on the previous analysis, it is presented below which of the initially formulated hypotheses were confirmed.

H1: Pharmacist expertise has positive implications regarding consumer loyalty to OTC products. (CONFIRMED)

$\mathrm{H} 2$ : Perceived risk related to the use of OTC products affects consumer loyalty. (CONFIRMED)

H3: Promotional activities related to OTC affect consumer loyalty. (NOT CONFIRMED)

H4: Consumer price sensitivity affects the loyalty to OTC products. (NOT CONFIRMED)

In order to test whether loyal consumers show more readiness to purchase OTC products, a simple regression analysis was applied (Table 6).

Table 6. Results of simple regression analysis (dependent variable is purchase intention)

\begin{tabular}{|l|l|l|l|l||}
\hline Variable & $\mathbf{B}$ & $\mathrm{T}$ & Sig. & VIF \\
\hline Loyalty & .500 & 5.865 & .000 & 1.000 \\
\hline
\end{tabular}

Source: Author's calculation based on SPSS

In accordance with Table 6, it can be concluded that the relationship between consumer loyalty towards OTC products and their readiness to make purchases is statistically significant. The problem of multicollinearity does not exist either, 
which can be seen from the value of VIF statistics. Therefore, in accordance with the formulated research framework, a formulated hypothesis can be confirmed:

H5: Consumer loyalty to OTC products has positive implications on consumer purchase intention. (CONFIRMED)

\section{Conclusion}

As it can be observed, the OTC market has been growing. Considering the fact that you do not have to use prescription to obtain these medications, the possibility for applying marketing tools when selling them is higher. In order to identify the factors that have the greatest impact on the loyalty of these products by consumers, we applied the statistical analysis which gives a genuine scientific and social contribution to this paper. Scientific justification of the paper is reflected in the possibility of expanding the existing knowledge of whether there are certain differences regarding the purchase of and loyalty to OTC products, while the social contribution can be observed through the possibility for pharmacies and other economic facilities to change their business policy based on the results of the research and intensify the application of marketing activities. By taking into consideration consumer loyalty as a separate segment of the analysis, and by applying correlation and regression analysis in the paper, it was observed that pharmacist expertise is one of the key indicators that contribute to the consumer visiting the pharmacy or retail store again and to continuing long-term cooperation with them. Therefore, as presented in the theoretical framework, it is of essential importance that people who are in direct contact with consumers are properly prepared, with sufficient knowledge to answer all possible questions and concerns that consumers might have. Also, the perceived risk which is present when using OTC products significantly affects the loyalty of the consumers. The greater perception of the risk regarding the use of these products, the greater the loyalty to their use. According to the research results, price sensitivity and promotional activities have no statistically significant impact on creating loyal consumers.

In one of the following papers, electronic media should also be included in the promotional activities, as one of the important factors that can determine the behaviour of consumers. When it comes to the buying behaviour of consumers, we found, with the applied analysis that consumers who are loyal to OTC products show more readiness to purchase. Some of the limitations of the research would primarily focus on the fact that the sample of respondents is small and that the research was carried out in the territory of Kragujevac. One of the significant shortcomings in the work is the lack of analysis regarding the type of OTC products, so some of the following research could include the examination of consumer attitudes, by taking into account different categories of these products. 


\section{References}

Almalak, H., Albluwi, Al., Alkhelb, DA., Alsaleh, HM., Khan, TM., Hassali, MA. \& Aljadhey, H. (2014). Student's attitude toward use of over the counter medicines during exams in Saudi Arabia. Saudi Pharmaceutical Journal, 22 (2), 107-112

Bahari, M. \& Ling, Y. (2010). Factors contributing to customer satisfaction with community pharmacies in Malaysia. Journal of Public Health, 18 (1), 35-41, doi: 10.1007/s10389009-0280-7

Chandra, A. \& Holt, G. (1999). Pharmaceutical advertisements: how do they deceive patients. Journal of Business Ethics, 18 (4), 359-366, doi:10.1023/A:1005924412406

Cho, J. \& Lee, T. (2013). The factors contributing to expenditures on over the counter drugs in South Korea. Value in Health Regional Issues, 2(1), 147-151, doi: 10.1016/j.vhri.2013.01.010

Cooper, R. (2013). Over the counter medicine abuse- review of the literature. Journal of Substance Use, 18 (2), 82-107, doi:10.3109/14659891.2011.615002

Creyer, E., Hrsistodoulakis, I. \& Cole, C. (2001). Changing a drug from Rx to OTC status: the consumer behaviour and public policy implications of switch drugs. Journal of Product \& Brand Management, 10(1), 52-64, doi: 10.1108/10610420110382821

Customer experience in the pharmaceutical sector: getting closer to the patient, Health Research Institute, 2013

Glasziou, P. P. (2002) Analgesia and public health: what are the challenges? American Journal of Therapeutics, 9 (3), 207-213

Guido, G., Pino, G. \& Frangipane, D. (2011). The role of credibility and perceived image of supermarket stores as valuable providers of OTC drugs. Journal of Marketing Management, Vol 27 (3), 207-224, doi: 10.1080/0267257X.2011.545669\}

Haddad, M., Hamam, F. \& Shakshir, S. (2013). General Public Knowledge, perception and practice towards pharmaceutical drug advertisements in the western region of KSA. Saudi Pharmaceutical Journal, 22 (2), 119-126, doi: 10.1016/j.jsps.2013.03.002

Hayashi, M., Masuda, S. \& Kimura, H. (2015). Key information providers, channels, and characteristics of Japanese consumers' informed choices of over-the-counter medications. SpringerPlus, 4:737, 2-11, doi: 10.1186/s40064-015-1549-7

Holmström I.K.,Bastholm-Rahmner P.,Bernsten, C.,Röing M. \& Björkman, I. (2014). Swedish teenagers and over the counter analgesics-responsible, casual or careless use. Research in Social and Administrative Pharmacy, 10 (2), 408-418, doi: 10.1016/j.sapharm.2013.06.004

Jobber, D. \& Fahy, J. (2006). Osnovi marketinga, Data Status

Kotler, P, Keller, K., (2007). Marketing menadžment, Data Status

Kwan, D., Boon, H., Hirschkorn, K., Welsh, S., Jurgens, T., Eccott, L., Heschuk, S., Griener, G., Cohen-Kohler, J. (2008). Exploring consumer and pharmacist views on the professional role of the pharmacist with respect to natural health products: a study of focus groups, BMC Complementary and Alternative Medicine, 8(1):40, doi: $10.1186 / 1472-6882-8-40$

Leeflang, P. \& Wieringa, J. (2010). Modeling the effects of pharmaceutical marketing, Marketing Letters, 21(2), 121-133, doi: 10.1007/s11002-009-9092-3\}

Lichtenstein, R., Ridgway N, Richard G. \& Netemeyer, R. (1993). Price perception and consumer shopping behaviour: A field study. Journal of Marketing Research, 30 (2), 234-245 
Lodorfos, G., Mulvana, K. \& Temperley, J. (2006). Consumer behaviour: experience, price, trust and subjective norms in the OTC pharmaceutical market. Innovative Marketing, Vol.2, Iss.3, 41-66

Lostakova, H. \& Horakova, V. (2014). Usefulness of Tools to Enhance Retention and Loyalty in Purchasing OTC Drugs from the Perspective of Clients of B\&M Pharmacies. Procedia - Social and Behavioural Sciences, 150, 576 - 589, doi: 10.1016/j.sbspro.2014.09.077

Mardanov, I. \& Ricks, J. (2013). Pharmacist professionalism, helpfulness, and consumer behaviour linkage, Journal of Medical Marketing,13(4) 221-230, doi: $10.1177 / 1745790413510237$

Maričić, B. (2002). Ponašanje potrošača, Ekonomski fakultet Beograd

Marinković, V. (2008). Kreiranje baze lojalnih potrošača, Ekonomski horizonti, 10, 109-127

Marinković, V. (2012). Marketinški aspekti satisfakcije i lojalnosti, Orijentacija na potrošače u savremenom bankarskom poslovanju, Ekonomski fakultet Univerziteta u Kragujevcu

Marinković, V., Senić, V. \& Dimitrovski, D. (2013). Merenje stavova potrošača o kvalitetu usluga u restoraterstvu. Teme, 1, 319-339

Nunnally, J. C. (1978). Introduction to Psychological Measurement. New York: McGraw-Hill.

Olbrich, R. \& Jansen, C. (2014). Price quality relationship in pricing strategies for private labels. Journal of Product \& Brand Management, 23 (6), 429-438

Piecuch, A. \& Kozłowska -Wojciechowska, M. (2013). Self-medication in Poland: the pharmacist's advisory role in Warsaw, Int J Clin Pharm, 35 (2):225-229

Pileggi,C., Mascaro,V., Bianco, A. \& Pavia, M. (2015). Over-the-Counter Drugs and Complementary Medications Use among Children in Southern Italy, BioMed Research International, 1-8

Porteous, T., Bond, C, Hannaford, P. \& Sinclair, H. (2005). How and why are non prescription analgesics used in Scotland? Family Practice, 22 (1), 78-85

Rosa-Díaz, I.M. (2004). Price knowledge: effects of consumers attitudes toward prices, demographics and sociocultural characteristics, Journal of Product and Brand Management, 13(6), 406-428

Rowley, A. (2014). Regulations of non prescription drug Product, www.fda.gov, 10.02.2018.

Shohel, M., Islam, T., Al-Amin, M., Islam, A. \& Rahman, M. (2013). Investigation of Consumer Attitudes, Intentions and Brand Loyal Behaviour on the OTC Drugs in Bangladesh. British Journal of Pharmaceutical Research 3(3): 454-464

Villako, P., Volmer, D. \& Raal, A. (2012). Factors influencing purchase of and counseling about prescription and otc medicines at community pharmacies in Tallinn, Estonia. Acta Poloniae Pharmaceutica- Drug Research, Vol. 69, No. 2, 335-340

Weiss, S. (2009). Compliance packaging for over-the-counter drug products, Journal Public Health, 17:155-164

Wieringa, J.E., Reber, K, C., Leeflang, P. (2015). Improving pharmacy store performance: the merits of over the counter drugs. European Journal of Marketing, 49, (7/8), 1276-1299

Zakaria, I., Rahman, B., Othman, A, K, Mohamed Yunus, N.A., Dzulkipli, R. M., \& Faiz Osman M.A. (2014). The Relationship between Loyalty Program, Customer Satisfaction and Customer Loyalty in Retail Industry: A Case Study. Procedia - Social and Behavioural Sciences 129, 23 - 30 


\section{KREIRANJE LOJALNOSTI POTROŠAČA U OBLASTI KORIŠĆENJA PROIZVODA KOJI SE IZDAJU BEZ LEKARSKOG RECEPTA}

Rezime: Ponašanje potrošača, pre svega, ispitivanje njihove lojalnosti, kao jedan od ključnih marketinških pojmova, predstavlja predmet razmatranja $u$ brojnim oblastima. Jedna od njih jeste i farmaceutski marketing. U radu je poseban akcenat stavljen na ispitivanje proizvoda koji se izdaju bez lekarskog recepta, odnosno nastoji se da se identifikuje koja varijabla ima najveći uticaj na lojalnost prema ovim proizvodima. Primenom kvantitativne analize ispitano je da li percipirani rizik, stručnost farmaceuta, reklamne aktivnosti i cenovna osetljivost utiču na stvaranje lojalnih potrošača. Takođe, cilj je bio da se utvrdi da li lojalnost potrošača prema ovim proizvodima rezultira kupovnim ponašanjem. Na osnovu primenjene korelacione i regresione analize potvrđeno je da statistički značajan uticaj na lojalnost potrošača imaju percipirani rizik i stručnost farmaceuta, kao i da između lojalnosti potrošača i spremnosti za kupovinu postoji statistički značajna veza.

Ključne reči: proizvodi koji se izdaju bez lekarskog recepta, lojalnost potrošača, percipirani rizik, stručnost farmaceuta, cenovna osetljivost, reklamne aktivnosti

\section{Authors' biographies}

Srđan Šapić is an Associate Professor at the Faculty of Economics, University of Kragujevac. He has been working at the Faculty of Economics in Kragujevac since 1998. He teaches at the bachelor studies the following subjects: International Marketing, International Business and Service Management and Marketing. $\mathrm{He}$ teaches Intercultural Marketing at the master study, study programme Business Economics and Management, and at doctoral academic studies, study programme Economics, International Marketing in a Global Environment. The main areas of his scientific research are international marketing, international business and service marketing, and within that, he intensively explores the cultural environment, customer satisfaction, and forms of internationalization.

Milan Kocić is an Associate Professor at Faculty of Economics University of Kragujevac. He has been teaching the subjects Market Communication and Direct Marketing at the undergraduate studies, Marketing Management at the master studies and Strategic Marketing at the $\mathrm{PhD}$ studies. He is a member of the Serbian Marketing Association and of the Promotion Team of the Faculty of Economics University of Kragujevac, as well as a member of the Undergraduate and Master Studies Committee.

Katarina Radaković is a Teaching Assistant at the Faculty of Economics, University of Kragujevac, Serbia, on the subjects of Marketing, Market Communication and Direct Marketing. She is a $\mathrm{PhD}$ student at the Faculty of Economics, University of Kragujevac. Katarina Radakovic is also a member of the Faculty Council, Commission for Quality at the Faculty of Economics University of Kragujevac, as well as member of Economic Research Center. Marketing is her main area of research. 